Науковий вісник НЛТУ України
Scientific Bulletin of UNFU
$\begin{gathered}\text { http://nv.nltu.edu.ua } \\ \text { https://doi.org/10.15421/40290417 }\end{gathered}$

А. С. Торосов, І. М. Жежкун, А. О. Калашніков, Ю. В. Харченко

Український НДІ лісового господарства і агромеліораиії ім. Г. М. Висоцького, м. Харків, Украйна

\title{
ЕКОНОМІЧНЕ ОБГРУНТУВАННЯ ВІКІВ ГОЛОВНИХ РУБОК ДЕРЕВОСТАНІВ
}

Розглянуто основні недоліки діючих у країні віків стиглості деревостанів лісових порід за лісівничими та економічними критеріями. Проведено порівняння діючих та проектних віків стиглості деревостанів основних лісотвірних порід за природними зонами та категоріями лісів. Для встановлення віків стиглості деревостанів та відповідно віків головних рубок необхідне комплексне використання кількісних і вартісних (грошових) показників. Наведено методику економічної оцінки запасів деревостанів за віками стиглості. Визначено показники загальних запасів деревостанів та їх розподілу за розмірно-якісними категоріями деревини в конкретному віці стиглості. Розраховано площі та проведено грошову оцінку запасів деревини сосни звичайної і дуба звичайного за проектними та діючими віками стиглості на період 2010-2040 рр. на прикладі лісогосподарських підприємств Чернігівського та Харківського ОУЛМГ. Здійснено порівняння вартісних показників запасів деревостанів сосни та дуба у віці стиглості. Встановлено, що підвищення віків стиглості та віків рубок призводить до тимчасового зменшення площі стиглих деревостанів та вартості запасів деревини. Проте з часом спостерігається їх збільшення. Доведено доцільність застосування проектних віків стиглості для зазначених головних деревних порід за категоріями лісів і природними зонами (Полісся, Лісостеп та Степ) в розглянутих регіонах.

Ключові слова: економічна оцінка; вік стиглості; повидільна база; запас деревостану; вартість деревини; порівняльна ефективність.

Вступ. Однією з найважливіших лісівничих та економічних проблем у лісовому господарстві $є$ визначення віків головної рубки лісів на основі встановлених віків стиглості деревостанів. 3 економічного погляду важливо як довго фінансові ресурси пов'язані у вигляді деревного запасу, а їх ефективне використання (отримання максимального доходу) залежатиме переважно від розподілу рубок за певними періодами. Рішення щодо того, в якому віці проводити лісозаготівлі і як їхній розмір повинен відповідати темпам росту насаджень, $є$ основою управління віковою структурою і складом лісів (Pirs, 2006).

Недосконалість та недоліки діючих віків стиглості деревостанів у лісах України негативно відображається на ефективності лісокористування. У сучасних реаліях дискусійним залишається питання економічного обгрунтування часу здійснення головних рубок. Тому виникає потребу проведення грошової оцінки запасів деревини залежно від віків стиглості деревостанів, а відповідно - і віків рубок головного користування.

Постановка проблеми. Останні віки стиглості та оптимальні віки рубок у лісах України для основних лісотвірних деревних порід були затверджені в 80-х роках минулого століття (Normativy, 1987). Серед недоліків діючих віків стиглості можна виділити їх неузго- дженість із сучасним поділом за категоріями лісів, недосконалість диференційованості за класами бонітету, недостатнє врахування розподілу насаджень за класами віку, що негативно позначається на ефективності лісокористування (Tkach et. al., 2002; Girs, 2011). Під час оцінювання віків кількісної та технічної стиглостей, за якими будуються розрахунки віків головних рубок лісу та обсягів користування деревиною (розрахункової лісосіки), лісовпорядкуванням недостатньо враховують технічну якість деревини та не застосовують показник iii грошової вартості (Girs et. al., 2004; Nakaz, 2000).

3 метою усунення лісівничо-таксаційних недоліків у встановлених віках стиглості та в оптимальних віках рубок у лісах України колектив науковців країни під керівництвом директора УкрНДІЛГА, проф. В. П. Ткача на заміну діючих віків стиглостей упродовж 20062007 рр. розробили новий проект віків стиглості деревостанів. У цьому проекті визначено віки стиглості для понад 30 деревних порід за природними зонами (Полісся і Лісостеп, Степ, Гірський Крим, Карпати) з урахуванням поділу лісів за категоріями (експлуатаційні та 3 обмеженим режимом лісокористування - захисні, рекреаційні, природоохоронні) та бонітетами (високобонітетні та низькобонітетні) (Proekt, 2007).

Однак недостатньо уваги приділено питанню еконо-

\section{Інформація про авторів:}

Торосов Артем Сергійович, канд. екон. наук, ст. наук. співробітник, завідувач лабораторії економіки.

Email: torosov@uriffm.org.ua

Жежкун Ірина Миколаївна, канд. екон. наук, ст. наук. співробітник, лабораторія економіки. Email: zhezhkun.iruna@gmail.com Калашніков Андрій Олегович, канд. екон. наук, ст. наук. співробітник, лабораторія eкономіки. Email: kalashnickov@uriffm.org.ua Харченко Юрій Володимирович, наук. співробітник, лабораторія економіки. Email: harchenko@uriffm.org.ua

Цитування за ДСту: Торосов А. С., Жежкун І. М., Калашніков А. О., Харченко Ю. В. Економічне обґрунтування віків головних рубок деревостанів. Науковий вісник НЛТУ України. 2019, т. 29, № 4. С. 82-85.

Citation APA: Torosov, A. S., Zhezhkun, I. M., Kalashnikov, A. O., \& Kharchenko, Yu. V. (2019). Economic justification of main felling age for forest stands. Scientific Bulletin of UNFU, 29(4), 82-85. https://doi.org/10.15421/40290417 
мічного обгрунтування оптимальних, з погляду лісівничих критеріїв, віків головних рубок деревостанів. Тому виникає потребу проведення грошової оцінки запасів деревини під час головних рубань і порівняння ефективності діючих та запропонованих у проекті віків стиглості деревостанів. Для встановлення віків стиглості деревостанів та відповідно віків рубок необхідне комплексне використання кількісних і вартісних (грошових) показників, що дасть змогу об'єктивно визначити лісівничо-економічну ефективність лісокористування. Тому метою дослідження $\epsilon$ проведення економічної оцінки запасів деревостанів сосни і дуба у віці головної рубки за діючими та проектними віками стиглості та порівняння їх вартості.

Матеріали і методика дослідження. Економічне обгрунтування віків рубок базується на проведенні узагальнених вартісних розрахунків за діючими і проектними віками стиглості та їх порівнянні для двох головних лісотвірних порід: сосни звичайної та дуба звичайного. Розрахунки провели на прикладі підприємств Харківського (Лісостепова і Степова природні зони) та Чернігівського ОУЛМГ (Поліська і Лісостепова природні зони). Як вхідну інформацію для розрахунків використали затверджені нормативно-довідкові матеріали, електронні повидільні бази лісовпорядкування лісогосподарських підприємств на 2010 р., діючі та проектні віки стиглості деревостанів, ставки рентної плати за спеціальне використання лісових ресурсів. Економічну оцінку здійснили за 10-річчя на період 2010-2040 pp. 3 визначенням прогнозних площ деревостанів для всіх категорій лісів: природоохоронних, рекреаційно-оздоровчих, захисних та експлуатаційних. Під час прогнозування площ деревостанів у віці стиглості площі насаджень 3 попереднього класу віку переходять у наступний. Для забезпечення однакових умов під час порівняння економічної оцінки деревини в динаміці (20102040 рр.) приймали таке:

- середній запас деревини відповідної породи на 1 га є незмінним на весь період розрахунків;

- товарна структура деревостанів визначена для діючих та проектних віків стиглості на рівні базового (2010 p.) та $\epsilon$ незмінною на весь період розрахунків;

- ставки рентної плати за заготівлю деревини основних лісових порід (Kodeks, 2018).

Для проведення розрахунків визначали відповідні показники щодо загальних запасів деревостану та їх розподілу за розмірно-якісними категоріями в конкретному віці стиглості. Вартість запасу деревини на 1 га за товарно-сортиментною структурою приймали на рівні базового 2010 р. На основі показників базового періоду визначали вартість загальних запасів деревини з урахуванням відповідних площ за віками стиглості та періодами: 2020, 2030, 2040 pp. За розрахованими показниками грошової оцінки запасів деревостанів сосни і дуба порівняли їхню вартість за діючими і проектними віками стиглості.

Викладення основного матеріалу. Вік стиглості, а відповідно і вік рубки, для сосни звичайної та дуба звичайного за проектом підвищено на 1-2 класи залежно від природної зони, категорії лісів, бонітету насаджень та походження. Зокрема для експлуатаційних лісів рівнинної частини України діючий вік стиглості сосни звичайної становить 81-90 років для всіх бонітетів, а проектний вік диференційовано за бонітетами: I і ви- ще - 91-100 років, II і нижче - 81-90 років. Істотнішу різницю у віках стиглості спостерігаємо для дуба звичайного. Для дуба насіннєвого походження зони Полісся та Лісостепу діючий вік стиглості II і вище бонітетів становить 111-120 років, а за проектом - 121-130 років. Проте за проектом виділяється I і вище бонітети, де вік стиглості дуба насіннєвого підвищено від 111-120 (чинні нормативи) до 131-140 років (Proekt, 2007).

Зазначені зміни у віках стиглості сосни та дуба призводять до змін в обсягах лісокористування за 10річними періодами впродовж 2010-2040 pр., а грошова оцінка деревини відповідно відображає цей динамічний процес. У соснових деревостанах Харьківського ОУЛМГ вартість запасів деревини за проектними віками стиглості стабільно зростає, порівняно з базовим 2010 р. (табл. 1).

Табл. 1. Порівняння вартості запасів соснових деревостанів за віками стиглості, тис. грн

\begin{tabular}{|c|c|c|c|c|}
\hline \multirow{2}{*}{ Вік стиглості } & \multicolumn{5}{|c|}{ Хік } \\
\cline { 2 - 5 } & 2010 & 2020 & 2030 & 2040 \\
\hline \multicolumn{5}{|c|}{ лісостеп } \\
\hline Проектні & 75849,2 & 109551,5 & 140636,4 & 249078,0 \\
\hline Діючі & 40855,4 & 78580,1 & 129433,2 & 204459,7 \\
\hline Різниця, +/- & $+34993,8$ & $+30971,5$ & $+11203,2$ & $+44618,3$ \\
\hline \multicolumn{5}{|c|}{ степ } \\
\hline Проектні & 113813,8 & 188758,1 & 521771,2 & 471756,3 \\
\hline Діючі & 38098,6 & 110964,4 & 325309,6 & 310917,6 \\
\hline Різниця, +/- & $+75715,2$ & $+77793,7$ & $+196461,7$ & $+160838,7$ \\
\hline \multicolumn{5}{|c|}{ разом по області } \\
\hline Проектні & 189663,0 & 298309,6 & 662407,6 & 720834,3 \\
\hline Діючі & 78954,0 & 189544,4 & 454742,8 & 515377,3 \\
\hline Різниця, +/- & $+110709,0$ & $+108765,2$ & $+207664,8$ & $+205457,0$ \\
\hline \multicolumn{5}{|c|}{ Чернігівська обл. } \\
\hline \multicolumn{5}{|c|}{ полісся } \\
\hline Проектні & 210445,4 & 443968,4 & 1043241,8 & 2023538,4 \\
\hline Діючі & 880800,3 & 1853704,2 & 1139694,2 & 1172796,3 \\
\hline Різниця, +/- & $-670354,8$ & $-1409735,8$ & $-96452,4$ & $+850742,0$ \\
\hline \multicolumn{5}{|c|}{ лісостеп } \\
\hline Проектні & 6264,9 & 9024,5 & 46558,2 & 125606,1 \\
\hline Діючі & 39622,3 & 112536,4 & 36444,5 & 46039,2 \\
\hline Різниця, +/- & $-33357,3$ & $-103511,9$ & $+10113,8$ & $+79566,8$ \\
\hline \multicolumn{5}{|c|}{ разом по області } \\
\hline Проектні & 216710,3 & 452992,8 & 1089800,0 & 2149144,4 \\
\hline Діючі & 920422,5 & 1966240,5 & 1176138,6 & 1218835,6 \\
\hline Різниця, +/- & $-703712,2$ & $-1513247,7$ & $-86338,6$ & $+930308,9$ \\
\hline
\end{tabular}

Ліси Харківської обл. за функціональним призначенням належить до захисних, рекреаційних та природоохоронних. За проектом диференціація віків стиглості сосни звичайної за I і вище та II і нижче класами бонітету (за чинними нормативами вік стиглості встановлено для всіх класів бонітету) істотно вплинула на розподіл площ і запасів деревостанів, товарно-сортиментну структуру деревини, що відповідно відобразилося на вартості деревини. Так, якщо в базовому 2010 р. за проектом питома вага соснових деревостанів I і вище бонітету становила $22 \%$, то в 2020 p. $-40 \%, 2030$ p. $-61 \%, 2040$ p. $-76 \%$ від загальної їх площі у відповідному віці стиглості. Тому спостерігаємо чітку тенденцію до збільшення вартості деревини - у 2040 р. вона перевищує відповідний показник 2010 р. майже в 2 рази.

У Чернігівській обл., на відміну від Харківської, значна частина лісів за функціональним призначенням $\epsilon$ експлуатаційними, для яких за проектом передбачають підвищення віку стиглості соснових деревостанів на один клас. Для порівняння - у захисних, рекре- 
аційних, природоохоронних лісах вік стиглості залишився без змін або навіть знизився. Застосування проектних віків стиглості в експлуатаційних лісах Чернігівської обл. призводить до тимчасового зменшення площ і запасів стиглих деревостанів. 3 огляду на це, починаючи $з$ 2030-2040 pp., вартість запасів соснової деревини зростає (див. табл. 1).

У дубових деревостанах Харківського та Чернігівського ОУЛМГ спостерігаємо аналогічну тенденцію 3 грошової оцінки деревини, порівнюючи діючі та проектні віки стиглості (табл. 2). У лісах Харківського ОУЛМГ вартість запасів деревини дуба в Лісостеповій зоні за проектними віками стиглості перевищує вартість за діючих віків стиглості за всіма періодами розрахунків. У Степовій зоні області значна частина низькопродуктивних дубових деревостанів порослевого походження, де спостерігаємо зниження товарності деревостанів і погіршення санітарного стану насаджень.

Табл. 2. Порівняння вартості запасів дубових деревостанів за віками стиглості, тис. грн

\begin{tabular}{|c|c|c|c|c|}
\hline \multirow{2}{*}{ Вік стиглості } & \multicolumn{4}{|c|}{ Рік } \\
\cline { 2 - 5 } Харківська обл. \\
\hline \multicolumn{5}{|c|}{ лісостеп } \\
\hline Запропоновані & 773603,7 & 759338,4 & 899476,3 & 1639422,2 \\
\hline Діючі & 313719,0 & 562760,4 & 409672,1 & 554201,5 \\
\hline Різниця, +/- & $+459884,7$ & $+196578,0$ & $+489804,2$ & $+1085220,7$ \\
\hline \multicolumn{5}{|c|}{ степ } \\
\hline Запропоновані & 416232,7 & 669713,4 & 268085,5 & 272684,0 \\
\hline Діючі & 246579,1 & 349346,4 & 407422,7 & 324883,5 \\
\hline Різниця, +/- & $+169653,6$ & $+320367,0$ & $-139337,2$ & $-52199,5$ \\
\hline \multicolumn{5}{|c|}{ по області } \\
\hline Запропоновані & 1189836,4 & 1429051,8 & 1167561,8 & 1912106,2 \\
\hline Діючі & 560298,2 & 912106,8 & 817094,8 & 879085,1 \\
\hline Різниця, +/- & $+629538,3$ & $+516945,0$ & $+350467,0$ & $+1033021,2$ \\
\hline \multicolumn{5}{|c|}{ Чернігівська обл. } \\
\hline \multicolumn{5}{|c|}{ полісся } \\
\hline Запропоновані & 60424,3 & 125487,8 & 251714,9 & 247582,7 \\
\hline Діючі & 91838,7 & 184684,0 & 176031,7 & 228313,9 \\
\hline Різниця, +/- & $-31414,4$ & $-59196,2$ & $+75683,2$ & $+19268,8$ \\
\hline \multicolumn{5}{|c|}{ по області } \\
\hline Запропоновані & 9538,3 & 39965,8 & 78336,6 & 129220,8 \\
\hline Діючі & 17795,9 & 43487,5 & 72135,8 & 118101,7 \\
\hline Різниця, +/- & $-8257,6$ & $-3521,7$ & $+6200,8$ & $+11119,1$ \\
\hline \multicolumn{5}{|c|}{} \\
\hline Запропоновані & 69962,6 & 165453,6 & 330051,5 & 376803,5 \\
\hline Діючі & 109634,6 & 228171,5 & 248167,5 & 346415,6 \\
\hline Різниця, +/- & $-39672,0$ & $-62717,9$ & $+81884,0$ & $+30387,9$ \\
\hline
\end{tabular}

Для таких насаджень проектом передбачено істотне зниження віків стиглості (на 1-3 класи віку), що приводить до збільшення площ i запасів деревостанів у 2020 р. майже в два рази. Надалі, з 2040 р. ситуація ста- білізується через підвищення частки високобонітетних насаджень та покращення їх товарної структури.

Для експлуатаційних лісів (Чернігівська обл.) проектом передбачено підвищення віку стиглості дубових деревостанів I бонітету на два класи, а II - на один клас віку. Проте, враховуючи, що частка високопродуктивних дубняків у Чернігівській обл. $є$ незначною, зростання вартості запасів деревостанів спостерігаємо 2030 р. для зони як Полісся, так і Лісостепу.

Висновки. У сучасних умовах запровадження економічних показників під час встановлення віків стиглості є об'єктивною необхідністю. Опрацьовано методичний підхід щодо економічної оцінки віків стиглості, проведені відповідні розрахунки та порівняння вартості запасів деревостанів за діючими та проектними віками стиглості. В експлуатаційних лісах соснових та дубових деревостанів (Чернігівська обл.) за проектними віками стиглості спостерігаємо тимчасове зменшення площ та вартості запасів. Однак з часом, починаючи 3 20302040 pр., вартісні показники зростають. У захисних, рекреаційних та природоохоронних лісах (Харківська обл.) показники вартості запасів соснових та дубових деревостанів більш стабільні з тенденцією до збільшення. Грошова оцінка запасів деревини в Харківській (Лісостеп, Степ) та Чернігівській областях (Полісся, Лісостеп) за фактичними та прогнозованими лісівничо-таксаційними показниками дубових і соснових деревостанів у динаміці (2010-2040 рр.) свідчить про обгрунтованість застосування проектних віків стиглості.

\section{Перелік використаних джерел}

Derevostany. (2007). Vik styhlosti derevostaniv. Kyiv: Derzhkomlishosp Ukrainy, 20 p. [In Ukrainian].

Girs, O. A. (2011). Maturity of forest stands and the use of wood resources in forests of different functional purposes. Korsun-Shevchenkivskyy: Vyd-vo Maydachenko, 315 p. [In Ukrainian].

Girs, O. A., Novak, B. I., \& Kashpor, S. M. (2004). Lisovporyadkuvannya. Kyiv: Aristej, 384 p. [In Ukrainian].

Kodeks. (2018). Podatkovyy Kodeks Ukrayiny. Retrieved from: http://kodeksy.com.ua/podatkovij_kodeks_ukraini.htm. [In Ukrainian].

Materialy. (1987). Normativno-spravochnye materialy dlya taksacii lesov Ukrainy ta Moldavii. Kyiv: Urozhaj, 560 p. [In Russian].

Metodyka. (2000). Metodyka vyznachennya rozrahunkovoyi lisosiky. Nakaz Derzhavnogo komitetu lisovogo gospodarstva Ukrayiny vid 14.09.2000 r, № 105. Retrieved from: https://zakon.rada.gov.ua/ laws/show/z0160-07. [In Ukrainian].

Pirs, P. (2006). Osnovy ekonomiky lisovoho hospodarstva. Kyiv: Ekoinform, 224 p. [In Ukrainian].

Tkach, V. P., Pasternak, V. P., \& Buksha, I. F. (2002). Ages of maturity in Ukrainian forests and ways of fellings system improvement. Lisivnytstvo i ahrolisomelioratsiia, 101, 98-104. [In Ukrainian].

A. S. Torosov, I. M. Zhezhkun, A. O. Kalashnikov, Yu. V. Kharchenko G.M. Vysotskiy Ukrainian Research Institute of Forestry and Forest Melioration, Kharkiv, Ukraine

\section{ECONOMIC JUSTIFICATION OF MAIN FELLING AGE FOR FOREST STANDS}

One of the most important economic problems in forestry is the definition of the ages of the principal felling of forests on the basis of established rotation stand ages. The main disadvantages of exploitability ages of stands of forestry species acting in the country under silvicultural and economic criteria are considered. In order to eliminate forestry inventory deficiencies in the established exploitability ages and in the optimal ages of felling in the forests of Ukraine on replacing the current ages of maturation, a new draft of rotation ages of stands has been developed. When establishing the rotation ages of stands and the age of felling, complex use of quantitative and cost (monetary) indicators is necessary; this will allow determining objectively the forestry and economic efficiency of forest exploitation. Therefore, there is a need for a monetary valuation of wood stocks at the principal felling and a comparison of the cost of existing and project rotation ages of stands. The method of economic estimation of forest stands stock by rotation ages is given. The indicators of total stands volume and their distribution according to the size-quality categories at a certain rotation age are determined. The area was calculated and an economic assessment of stand volumes of the Scots pine and 
Pedunculate oak forests for the design and operational rotation ages for the period of 2010-2040 was made, on the example of the forest enterprises of Chernihiv and Kharkiv Regional Departments of Forestry and Hunting. According to the economic evaluation indicators, the existing and design rotation ages of the pine and oak stands were compared. There is a temporary decrease in the area and cost of stocks in exploited forests of pine and oak stands (Chernihiv Region). However, over time, from 2030-2040 the situation is stabilizing with the tendency to increase these indicators. In the protective, recreational and nature protection forests (Kharkiv Region) the cost indicators of stocks of pine and oak forests are constantly increasing. The expediency of application of project exploitability ages for the main tree species by forest categories in different natural zones (Polissya, Forest-steppe and Steppe) has been proved.

Keywords: economic evaluation; exploitability age; subcompartment base; growing stock; the cost of wood; comparative effectiveness. 